\title{
TRANSBOUNDARY AIR-POLLUTION TRANSPORT IN THE CZECH-POLISH BORDER REGION BETWEEN THE CITIES OF OSTRAVA AND KATOWICE
}

\author{
Libor Černikovský, Blanka Krejčí, Zdeněk Blažek, Vladimíra Volná \\ Czech Hydrometeorological Institute, Praha, Czech Republic
}

\section{SUMMARY}

Objective: The Czech Hydrometeorological Institute (CHMI) estimated the transboundary transport of air pollution between the Czech Republic and Poland by assessing relationships between weather conditions and air pollution in the area as part of the "Air Quality Information System in the Polish-Czech border of the Silesian and Moravian-Silesian region" project (http://www.air-silesia.eu). Estimation of cross-border transport of pollutants is important for Czech-Polish negotiations and targeted measures for improving air quality.

Methods: Direct measurement of $\mathrm{PM}_{10}$ and sulphur dioxide $\left(\mathrm{SO}_{2}\right)$ concentrations and the direction and wind speed from measuring stations in the vicinity of the Czech-Polish state border in 2006-2012.

Results: Taking into account all the inaccuracies, simplifications and uncertainties, by which all of the measurements are affected, it is possible to state that the $\mathrm{PM}_{10}$ transboundary transport was greater from the direction of Poland to the Czech Republic, rather than the other way around. Nevertheless, the highest share of the overall $\mathrm{PM}_{10}$ concentration load was recorded on days with a vaguely estimated airflow direction. This usually included days with changing wind direction or days with a distinct wind change throughout the given day. A changeable wind is most common during low wind speeds. It can be assumed that during such days with an ambiguous daily airflow, the polluted air saturated with sources on both sides of the border moves from one country to the other. Therefore, we could roughly ascribe an equal level of these concentrations to both the Czech and Polish side.

Conclusions: $\mathrm{PM}_{10}$ transboundary transport was higher from Poland to the Czech Republic than from the opposite direction, despite the predominant air flow from the Czech Republic to Poland.

Key words: air quality, Czech-Polish border, Moravian-Silesian region, Silesian Voivodeship, relationship between meteorology and ambient concentrations, transboundary transport

Address for correspondence: L. Černikovský, ČHMÚ - pobočka Ostrava, K Myslivně 3/2182, 70800 Ostrava-Poruba, Czech Republic. E-mail: cernikov@chmi.cz.

http://dx.doi.org/10.21101/cejph.a4532

\section{INTRODUCTION}

From a long-term perspective, the most serious problem of transboundary transport in the Moravian-Silesian region is the level of air pollution by particles of anthropogenic origin. The origin of these particles in the area is a high industrial production concentration, high agglomeration density with a local fossil-fuels heating and a dense traffic infrastructure.

The $\mathrm{PM}_{10}$ suspended particles' concentration in the area every year exceeds the annual limit value for human health protection of $40 \mu \mathrm{g} . \mathrm{m}^{-3}$; and the daily limit value of $50 \mu \mathrm{g} \cdot \mathrm{m}^{-3}$ is exceeded in a many-fold higher amount than that tolerated by law, i.e. 35 days in the calendar year. The $\mathrm{PM}_{10}$ concentration level on both sides of the border is fairly similar. Benzo[a]pyrene in $\mathrm{PM}_{10}$ poses the largest health threat, as its annual average concentration exceeded multiplicatively the target value of $1 \mathrm{ng} . \mathrm{m}^{-3}$, where the concentration on the Polish border side is higher than on the Czech side. The ambient air sulphur dioxide pollution $\left(\mathrm{SO}_{2}\right)$ in the Silesian voivodship is roughly double in comparison to the MoravianSilesian region. Significantly higher $\mathrm{SO}_{2}$ concentration in the
Silesian voivodship is largely a result of local heating in which lower-quality and higher-sulphur-content fuels are utilised $(1,2)$.

A predominant airflow from the southwest is typical for the area of northeast Moravia in the Czech Republic and is related to the orographic influence of the Moravian Gate. This influence is even evident in adjacent border areas of the Silesian Voivodeship in Poland. In the transboundary area of Silesia and Moravia the steady airflow is mainly connected with the cyclonic (low pressure) type of weather with mostly higher airflow speeds and good dispersion conditions. During this airflow, a relatively cleaner air from less polluted areas of the Czech Republic is transported to the transboundary area of Moravia and Silesia. Conversely, northeast and variable wind flows with low wind velocities are associated with anticyclonic situations (high-pressure systems), and are often accompanied by deteriorated dispersion conditions, especially during the cold period of the year. Generally, during mainly good dispersion conditions, the pollutants are usually transported from the Czech Republic into Poland, whilst during predominantly worsened dispersion conditions, it is the other way around. Locations in the centre of the transboundary area are pol- 
luted in both directions of the airflow by emissions from sources located in the edge areas. A year-to-year concentration changeability of $\mathrm{PM}_{10}, \mathrm{NO}_{2}$ and $\mathrm{SO}_{2}$ is high and depends on meteorological conditions mainly in the cold half of a year. The exceptionally high levels are caused by long-lasting inversion situations in the whole area during winter season, i.e. from December to February. The difference in concentrations in various locations is caused by a different geographical location and location in relation to the sources of emissions (2).

\section{METHODS}

Transboundary air-pollution transport is a very complicated and sensitive issue, the solution of which is difficult. Some of the reasons for this are the frequently complicated state border lines, transboundary airflow time variability (considering both direction and wind speed), ground layer vertical stability and time variability, varied distribution and characteristic of emission sources on both sides of the border (low/high sources) and also the long-distance transport of pollutants in the atmosphere. The result is that the transboundary transport of pollutants across a certain stretch of the state border can be only estimated. For estimation, either mathematical modelling methods (3) of pollutant propagation or direct pollutant measurements and necessary meteorological measurements along the state border can be used, as well as study of the dependence of measured concentrations on airflow. However, this approach only enables assessment of transboundary transport on the ground-floor level but not in the higher atmospheric layers. For these purposes, distance or flight measurements are necessary. At the European level, the European Monitoring and Evaluation Programme (EMEP) (4) focuses on assessment of the transboundary transport of acidification and eutrophication and addresses the formation of ground level ozone and, more recently, of persistent organic pollutants (POPs), heavy metals and particulate matter. Nevertheless, EMEP is not focused on specific regional borders unlike the work presented in this article.

As a part of the "Air Quality Information System in the PolishCzech border in the Silesian and Moravian-Silesian Region" project, the CHMI estimated the transboundary transport of air pollution between the Czech Republic and Poland by assessing relationships between weather conditions and the air pollution in the area, i.e. by utilising direct-measurement concentrations of $\mathrm{PM}_{10}$ and $\mathrm{SO}_{2}$ and the direction and wind speed from sites in the vicinity of the state border in 2006-2012. $\mathrm{PM}_{10}$ concentrations were chosen for their severity in the researched area; the high level of air pollution caused by particles of anthropogenic origin is the most serious issue in the transboundary area. The $\mathrm{SO}_{2}$ concentrations do not exceed the limits, but both concentrations are much higher on the Polish side than on the Czech side, whilst $\mathrm{SO}_{2}$ is an appropriate indicator for anthropogenic processes, i.e. winter heating and continually run industrial sources in summer. The assessment stemmed, among others, from a detailed pollutionmeteorological relationships analysis (2).

For the transboundary air-pollution transport estimate in the project area, available measurements from national pollution networks in the Czech-Polish border area of Silesia and Moravia were used. The data were provided by the CHMI and by the Voivodeship Inspectorate of Environmental Protection in Katowice. Whilst there is a total of 14 monitoring stations in the approx. 15-kilometre area along the state border, only 4 of them are situated within 1 kilometre of the state border. The assessment also includes the Ostrava-Radvanice station, which lies downwind from the nearby ArcelorMittal Ostrava industrial compound, and which is run by Public Health Institute Ostrava. Apart from air pollution levels, monitoring stations usually monitor wind direction and wind speed as well (Fig. 1).

The evaluated measurements encompass years 2006-2012. For each station involved, the available 1-hour and/or 24-hour average $\mathrm{PM}_{10}$ and $\mathrm{SO}_{2}$ concentrations were assessed as well as the 1-hour average wind direction values and values for wind speeds at the standard height of 10 metres above ground level on a given station or nearby meteorological station. With wind speeds of up to 0.2 $\mathrm{m} . \mathrm{s}^{-1}$, both the direction and wind speed were labelled as windless conditions (calm), whereas with wind speeds of $0.3 \mathrm{~m} \cdot \mathrm{s}^{-1}$ and over the wind directions were divided into a 16-direction scale.

For the purposes of the 24-hour $\mathrm{PM}_{10}$ concentrations assessment from the Věřnovice and Godów stations, the average daily directions and wind speeds were derived from the hourly directions and wind speeds at the Verřnovice station. On days where for at least 16 hours (i.e. $2 / 3$ of 24 hours) the wind was blowing from any one of the quadrants $0-90^{\circ}, 90-180^{\circ}, 180-270^{\circ}, 270-360^{\circ}$, and at the same time the frequency of wind directions in the opposite quadrant was less than 6 (i.e. in $1 / 4$ of 24 hours), the average daily wind direction was determined using the vector sum of the hourly wind vectors.

For the needs of assessing the effect of the measured concentrations on the airflow direction at a given station, an order was established for each term, considering the continuous airflow in the same direction. During the assessment, terms with the first appearance of a given wind direction were excluded, which revealed that the assessment of effects of measured concentrations on the airflow directions included only the terms during which the wind at the station was blowing from a given direction for at least one hour. By contrast, the processing excluded hours after a winddirection change, during which the average concentration can be influenced by a different-direction airflow during the preceding hour, i.e. by the transport of pollutants from a different direction.

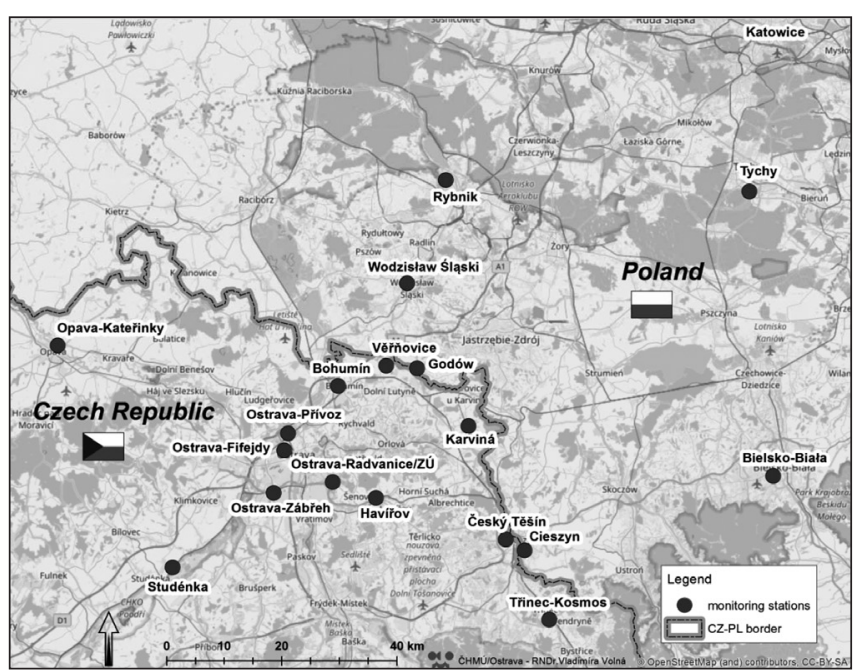

Fig. 1. Automated monitoring stations in the Czech-Polish border region between the cities of Ostrava and Katowice. 
The pollutant concentration roses illustrate the wind directions during which the highest concentrations are measured at a given site, or more precisely which direction the level of air pollution is most affected from for a given location. One of the characteristics is an average concentration from particular direction

$$
\bar{c}_{j}=\frac{1}{n_{j}} \sum_{i=1}^{n_{j}} c_{j}
$$

where $\bar{c}_{j}$ is particular 1-hour concentration assigned to selected wind direction $j$ and $n_{j}$ is their total number. The direction dependency of pollution on individual stations is also documented by roses of the relative short-term concentration above selected level

$$
f_{X j}=\frac{1}{n_{X}} \sum_{i=1}^{n_{j}}\left(c_{j}>X\right)
$$

where $n_{x}$ is total number of 1-hour concentrations above the level X without reference to the direction. Another way of illustrating the dependency of pollution level on the airflow direction are the so called roses of concentration load of a given location

$$
L_{j}=\frac{\sum_{i=1}^{n_{j}} c_{j}}{\sum_{i=1}^{n} c_{i}}
$$

where $c_{i}$ is particular 1-hour concentration without reference to the direction. The disadvantage of this evaluation method is the fact that it assesses and compares sums of concentrations, i.e. the same sum can be achieved both by the sum of a small number of high concentrations and large number of small concentrations, the health impact of which is obviously much less significant.

The entire assessed period was divided into two parts, namely the heating and non-heating seasons. Heating seasons began in the
September-October period on the first day, after which at least 3 days with the minimum average daily temperature $\mathrm{T}_{d}<13^{\circ} \mathrm{C}$ followed, and it always ended in the March-April period on the last day, after which at least 3 days with $\mathrm{T}_{\mathrm{d}}>13^{\circ} \mathrm{C}$ followed.

Assessment of pollutant-meteorological relationships was extensive. The frequencies of wind directions at individual measuring stations and pollutant levels, depending on the airflow direction in heating and non-heating seasons of the year, were described in detail. The summarizing final report of the partial project task in Czech language can be found on the project web site (5). Only selected results are quoted in this article.

\section{RESULTS}

\section{Concentrations Depending on the Airflow Direction}

- Studénka station is located south-west of Ostrava-Karviná region, approx. 10 kilometres from the southern edge of Ostrava and approx. 32 kilometres from the Czech-Polish state border. During west sector airflow, i.e. from the less polluted Oderské vrchy mountains and foothills of Jeseníky mountains, the $\mathrm{PM}_{10}$ concentrations over a period of steady airflow decreased below $20 \mu \mathrm{g} \cdot \mathrm{m}^{-3}$. During airflow from the south-west quadrant, i.e. from the Moravian Gate and middle Moravia, the $\mathrm{PM}_{10}$ concentrations decreased as well, but only to about $35 \mu \mathrm{g} \cdot \mathrm{m}^{-3}$, that is, they were higher than from the western "clean" sector. During north-east directions and calm the $\mathrm{PM}_{10}$ and $\mathrm{SO}_{2}$ concentrations were significantly higher than during other airflow directions. This is without a doubt the consequence of polluted air transport from the Ostrava-Karviná and Poland area.

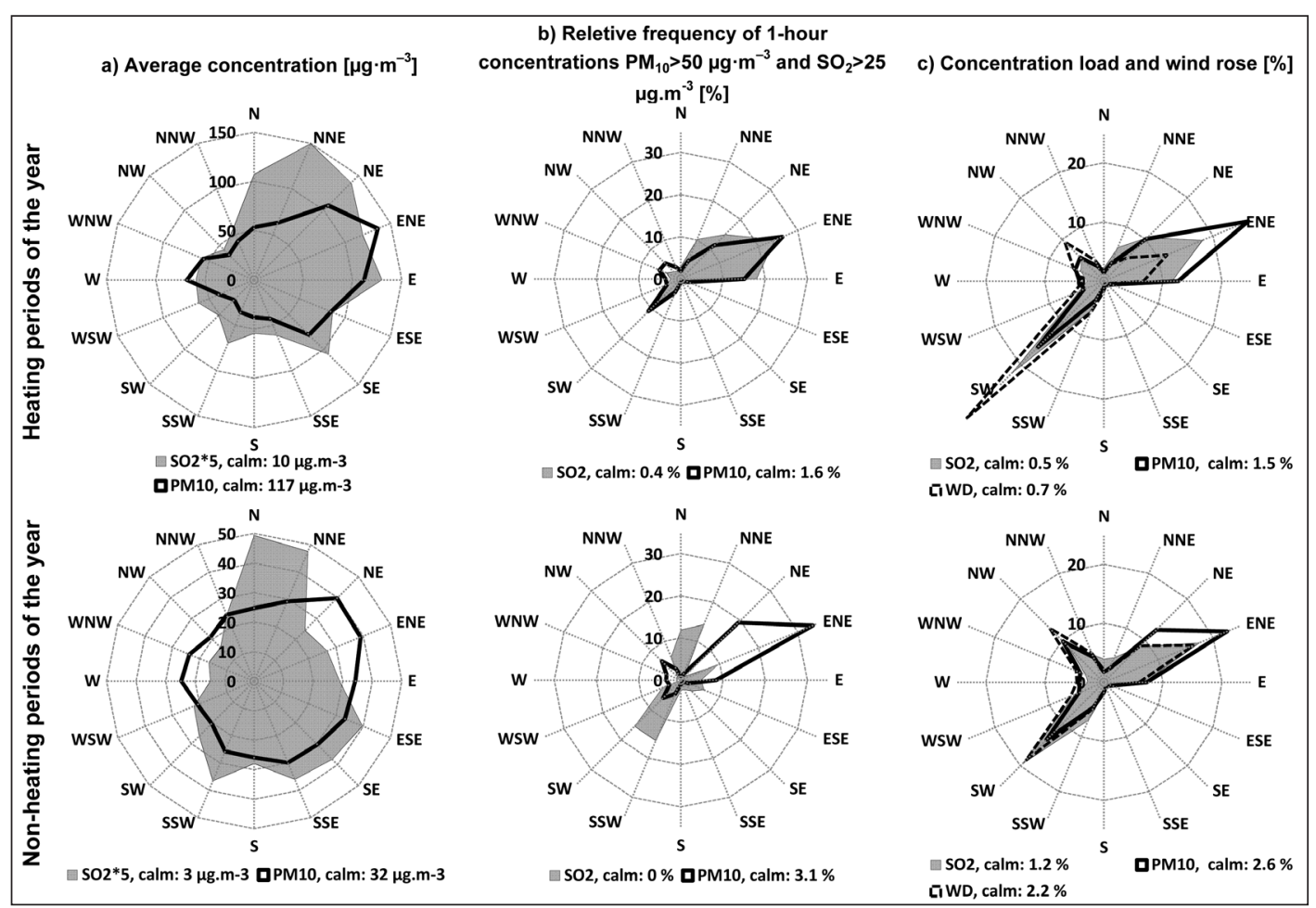

Fig. 2. Station Věřňovice (CZ-PL border), 1-hour concentrations characteristics in dependence on wind direction, 2006-2012, steady airflow at least two consecutive hours.

Number of 1-hour concentrations in heating periods of the year: $\mathrm{PM}_{10}>50 \mu \mathrm{g} \cdot \mathrm{m}^{-3}: 5987$, i. e. $34.8 \%$ of all available values; $\mathrm{SO}_{2}>25 \mu \mathrm{g} \cdot \mathrm{m}^{-3}>2629$, i. e. $15.5 \%$ Number of 1 -hour concentrations in non-heating periods of the year: $\mathrm{PM}_{10}>50 \mu \mathrm{g} \cdot \mathrm{m}^{-3}: 1007$, i. e. $10.5 \%$ of all available values; $\mathrm{SO}_{2}>25 \mu \mathrm{g} \cdot \mathrm{m}^{-3}>84$, i. e. $0.9 \%$ 
- Verřnovice station is located in the direct vicinity of the Czech-Polish state border on Czech territory. During west sector airflow the $\mathrm{PM}_{10}$ concentrations were higher than in Studénka, because there is no similarly lightly polluted area west of Věřnovice. During south-west quadrant airflow, i.e. from Ostrava town direction, the concentrations decreased to about the same level as in Studénka. During north-east sector directions and wind calm the concentrations were significantly higher than during other airflow directions. This is without a doubt the consequence of polluted air transport from Poland to the Czech Republic (Fig. 2 and 3).

- Wodzisław Śląski station is located ca. 10 kilometres from the Czech-Polish state border on Polish territory. Here the concentrations of both $\mathrm{PM}_{10}$ and $\mathrm{SO}_{2}$ were higher than in Studénka and Věřnovice. The south-west and north-east quadrant airflow concentrations were fairly similar, which points to the fact that the station is located in a highly-polluted area.

\section{Expert Estimate of Transboundary Transport}

The Czech station Veřnovice and the Polish station Godów were considered representative for a quantification estimate of transboundary air-pollution transport at ground level over a stretch of the state border ca. between towns of Bohumín and Karviná, i.e. in a section that represents the main pollution transport area between the Czech Republic and Poland in the Moravian-Silesian region. The horizontal distance between these stations is about 3.5 $\mathrm{km}$. Below a quantification estimate of transboundary transport for $\mathrm{PM}_{10}$ is described, based on measured data in the X/2009$\mathrm{XII} / 2012$ period.
Daily types of airflow were calculated and for days with an unequivocal type of airflow, the average wind speeds and average concentrations for individual wind directions were calculated. The share of days, for which it was not possible to clearly determine the daily airflow type, was nearly $50 \%$ in the cold and approx. $65 \%$ in the warm period of a year (Fig. 3). If we combine the pollution data from wind directions, which can be at considered transboundary on this section of the border, we can calculate the quantification estimate of the $\mathrm{PM}_{10}$ transboundary transport share in the state border section between Věřnovice and Godów stations at approx. $3 \mathrm{~m}$ above ground level, i.e. the impact on the overall ambient concentrations. In this section, the airflow from Poland to the Czech Republic from north-north-west (NNW) across north (N) all the way to east (E) and from the Czech Republic to Poland from west (W) across south (S) all the way to south-south-east (SSE) can be clearly considered transboundary.

On days with a steady airflow with airflow direction from Poland to the Czech Republic there was both much higher pollution burden and much higher frequency of days with an average $\mathrm{PM}_{10}$ concentration above $50 \mu \mathrm{g} \cdot \mathrm{m}^{-3}$ (daily limit value) and 100 $\mu \mathrm{g} \cdot \mathrm{m}^{-3}$ higher than the other way around, both during the heating and non-heating half of the year. The highest frequency of days with daily $\mathrm{PM}_{10}$ concentrations above $50 \mu \mathrm{g} \cdot \mathrm{m}^{-3}$ and $100 \mu \mathrm{g} \cdot \mathrm{m}^{-3}$ occurred on days with unclearly determinable airflow direction: mostly days with changing wind direction or days with a significant wind change throughout. Changing wind direction is most common during low wind speeds. Although during a steady airflow the air coursed more frequently from the Czech Republic to Poland, the pollution burden was higher in the opposite direction, i.e. from the Czech Republic to Poland (Fig. 3 and 4, Table 1).

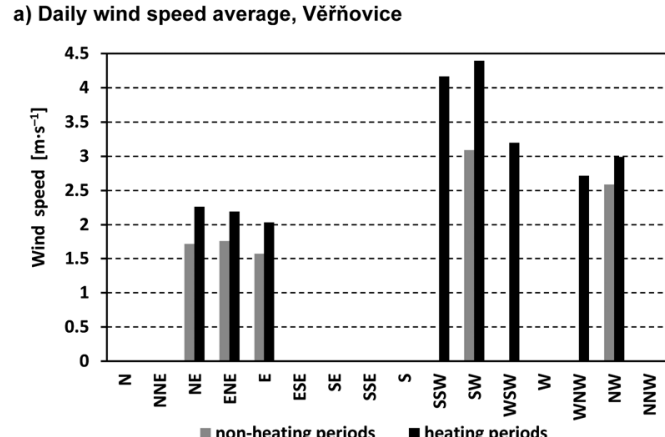

c) Daily $\mathrm{PM}_{10}$ averages, heating periods

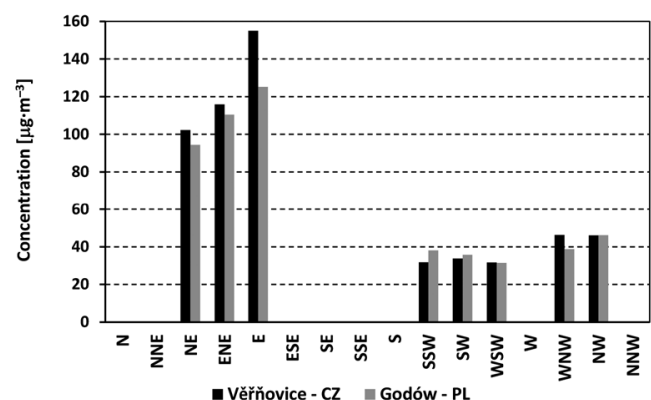

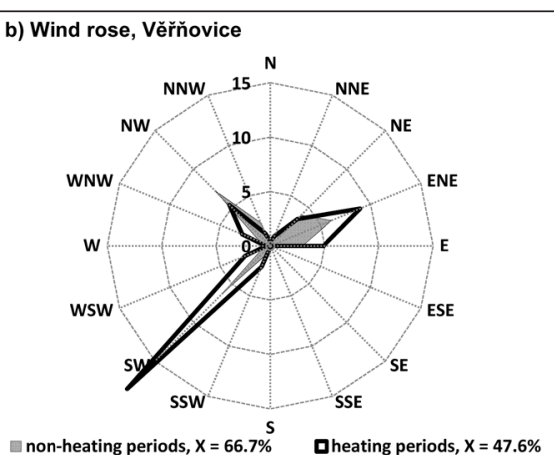

d) Daily $\mathrm{PM}_{10}$ averages, non-heating periods

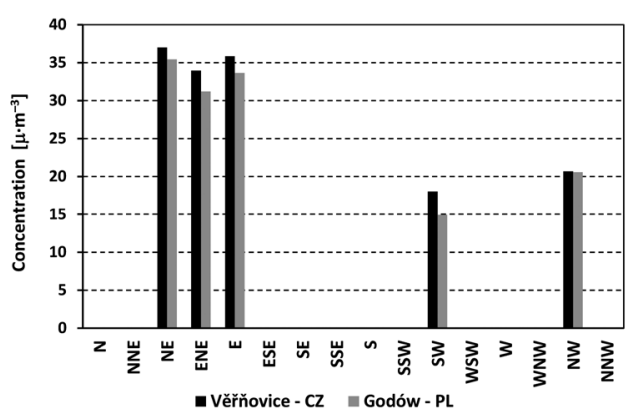

Fig. 3. Locations Věřňovice (CZ) and Godów (PL), 24-hour wind and $P M_{10}$ characteristics in dependence on wind direction, X/2006-XII/2012 (only directions with at least 12 daily incidence are shown).

$X$ means share of days with undetermined daily type of wind direction 
Table 1. Expert estimate of the $P M_{10}$ transboundary transport in \% in the part of the CZ-PL state border between Věřnovice (CZ) and Godów (PL) at a level of about $3 \mathrm{~m}$ above the surface, X/2009-XII/2012

\begin{tabular}{|l|l|c|c|c|c|c|c|}
\hline \multirow{2}{*}{$\begin{array}{l}\text { Transboundary } \\
\text { transport }\end{array}$} & \multirow{2}{*}{ Daily type of wind direction } & \multicolumn{2}{|c|}{ Heating periods } & \multicolumn{2}{|c|}{ Non-heating periods } & \multicolumn{2}{|c|}{ Whole year } \\
\cline { 3 - 8 } & & Věřňovice & Godów & Věřňovice & Godów & Věřnovice & Godów \\
\hline From PL to CZ & NNW + N + NNE + NE + ENE + E & 28.8 & 26.9 & 18.1 & 19.1 & 26.4 & 25.2 \\
\hline From CZ to PL & SSE + S + SSW + SW +WSW + W & 18.9 & 20.9 & 8.1 & 7.8 & 16.5 & 18.1 \\
\hline \multirow{2}{*}{ Undetermined } & Other directions & 6.2 & 6.1 & 8.4 & 9.1 & 6.7 & 6.8 \\
\cline { 2 - 9 } & Undetermined & 46.1 & 46.1 & 65.4 & 64.1 & 50.4 & 50.0 \\
\hline Total & All directions & 100.0 & 100.0 & 100.0 & 100.0 & 100.0 & 100.0 \\
\hline
\end{tabular}

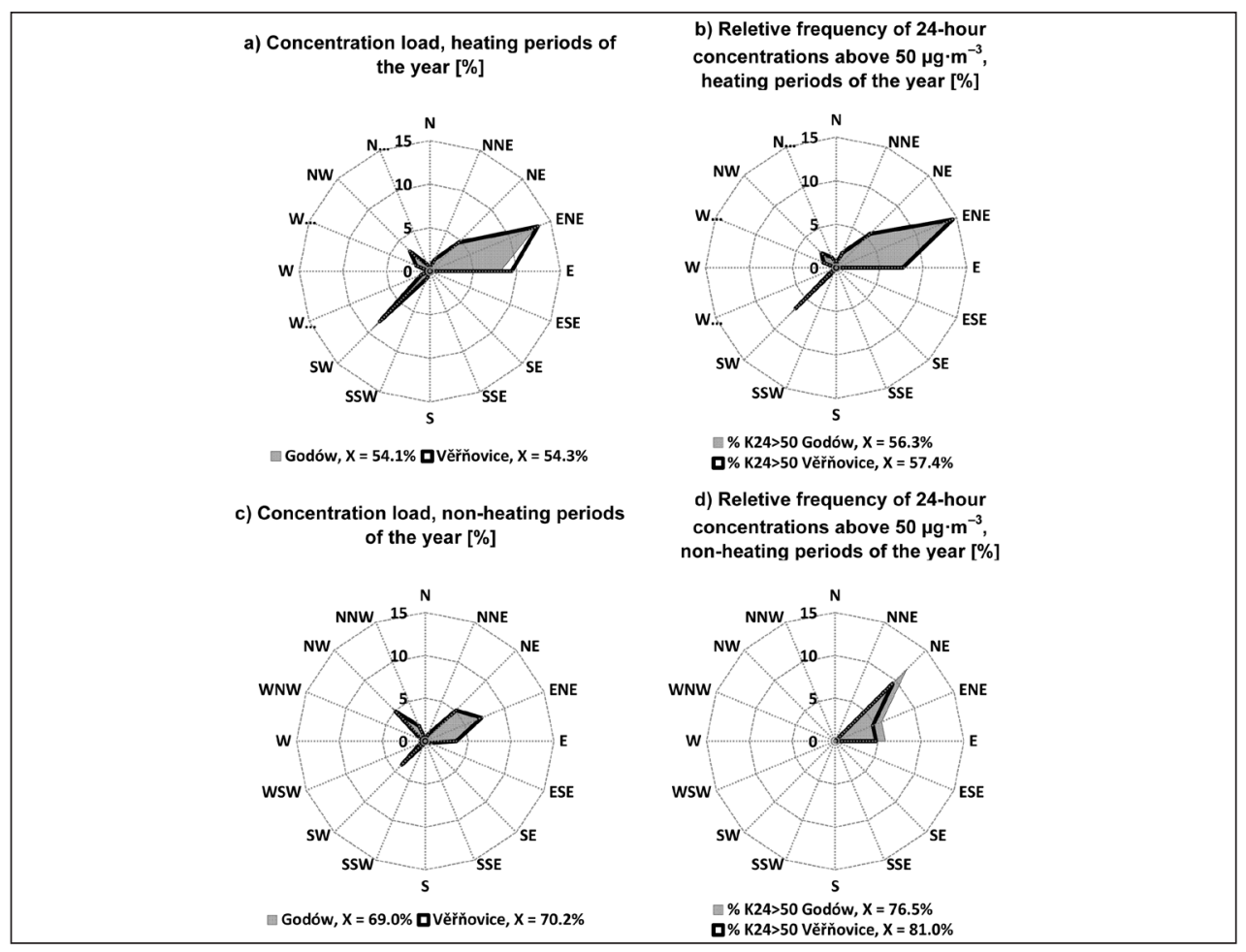

Fig. 4. Locations Věřňovice (CZ) and - Godów $(P L)$, 24-hour $P M_{10}$ characteristics in dependence on wind direction, X/2006XII/2012.

$\mathrm{X}$ means share of days with undetermined daily type of wind direction

\section{DISCUSSION}

If the air flows steadily for a longer period, i.e. its direction does not change significantly, the pollutant concentration levels decrease or increase depending on the airflow direction. From these dependencies, the air-pollution transport between areas can be inferred. Significant dependencies of concentration levels on steady airflow direction can documented in several location, which are situated approximately on the axis of the prevalent south-west - north-east airflow in the investigated border area.

It can be stated that in the border region of Silesia and Moravia, pollutant concentrations during steady airflow are higher during wind direction from Poland to the Czech Republic rather than the other way around. During steady south-west airflow there are good dispersion conditions in the area and during pollutant transport a favourable vertical dispersion usually occurs as well, so the resulting pollution concentrations at ground level are not as high as during the north-east wind airflow, which is often associated with worse dispersion conditions.
As mentioned above, the quantification of transboundary pollutant transport across the state border is, amongst other factors, often complicated by the complex shape of the state border itself. For a quantification estimate of transboundary pollutant transport based on pollution-meteorological relationships, it is necessary for the measurement stations to be as close to the state border as possible and that there are no other pollution sources between the station and border (if possible). These conditions are met by the Czech Věřnovice and the Polish Godów stations. The behaviour of daily $\mathrm{PM}_{10}$ concentrations on the Věřnovice and Godów stations in the X/2009-XII/2012 period was similar, and the measurement is comparable on both stations from both the size and wind direction dependency standpoint. We can therefore exclude the prevailing pollution effect of both the nearby Veřrnovice municipality and Dětmarovice power plant on $\mathrm{PM}_{10}$ concentrations, as both of the sources are situated in different directions from the stations. Measurements taken at these stations are therefore usable for a quantification estimate of the transboundary transport. 


\section{CONCLUSIONS}

Taking into account all the inaccuracies, simplifications and uncertainties, by which the evaluations are affected, it is possible to state that:

- The $\mathrm{PM}_{10}$ transboundary transport was higher from Poland to the Czech Republic than from the Czech Republic to Poland, despite the predominant air flow from the Czech Republic to Poland. This finding roughly corresponds with the modelling results of annual $\mathrm{PM}_{10}$ averages in Jančík et al. (3).

- The highest share of the overall $\mathrm{PM}_{10}$ pollution burden occurred on days with unclearly determinable daily airflow direction or days with a significant wind change throughout. Changing wind direction is most common during low wind speeds. It can be assumed that during these days with unclearly determinable daily airflow direction the polluted air, saturated with sources on both sides of the border, moves from one side of the border to the other. We could, therefore, were roughly ascribe concentrations of these days equally to both the Czech and Polish side.

\section{Acknowledgements}

The assessment was composed as a part of the "Air Quality Information System in the Polish-Czech border in the Silesian and Moravian-Silesian Region" project, which was financed by the Transboundary co-operation operational programme the Czech Republic-Poland 2007-2013 (registration number of the project: CZ.3.22/1.2.00/09.01610).

\section{REFERENCES}

1. European Environmental Agency. Air quality in Europe - 2014 report [Internet]. Copenhagen: EEA; 2014 [cited 2016 Nov 17]. Available from: http://www.eea.europa.eu/publications/air-quality-in-europe-2014.

2. Blažek Z, Černikovský L, Krajny E, Krejčí B, Ośródka L, Volná V, et al. The influence of meteorological conditions on air quality in the border region of Silesia and Moravia [Internet]. Prague: Czech Hydrometeorogical Institue; 2013 [cited 2016 Nov 17]. Available from: http://www. air-silesia.eu/files/file/air_silesia/publikace_pdf. (In Czech, Polish.)

3. Jančík P, Bitta J, Pavlíková I, Hladký D. Air pollution dispersion model ADMoSS [Internet]. Ostrava: VŠB - Technical University of Ostrava; 2013 [cited 2016 Nov 17]. Available from: http://www.air-silesia.eu/files/ file/air_silesia/raport/AirSilesia_raport5cz_.pdf. (In Czech.)

4. EMEP. The European Monitoring and Evaluation Programme [Internet]. Geneva: UNECE [cited 2016 Nov 17]. Available from: http://www.emep. int.

5. Blažek Z, Černikovský L, Krejčí B, Volná V. Evaluation of the Transboundary Air-Pollution Transport within the project "The influence of meteorological conditions on air quality in the border region of Silesia and Moravia". Final report [Internet]. Ostrava: Czech Hydrometeorogical Institue; 2013 [cited 2016 Nov 17]. Available from: http://www. air-silesia.eu/files/file/air_silesia/raport/AirSilesia_CHMU_Transhranicni_prenos_zaverecna_zprava_FINAL8_.pdf (In Czech.)

Received August 28, 2015 Accepted in revised form November 17, 2016 